\title{
DUALITAS HUKUM WARIS MINANGKABAU DAN ISLAM (STUDI KONSTRUKSI SOSIAL MASYARAKAT MUSLIM MINANGKABAU DI MALANG)
}

\author{
Anwar Fauzi \\ Fakultas Syari'ah UIN Maulana Malik Ibrahim Malang \\ e-mail:anwar_fauzi@yahoo.com
}

\begin{abstract}
Abstrak
One of interesting customary laws is the implementation of customary law of inheritance system of Minangkabau society. Minangkabaw society implements inheritance system from mother's lineage. It contradicts with the inheritance system in Islam which admits father's lineage system. The aim of this research is to describe social construction pattern and inheritance system which are constructed by Minangkabaw society in Malang. Method which is applied in this research is field research with qualitative descriptive approaches. From the result of this research, the researcher concludes that social construction which is constructed by Minangkabaw society in Malang is adaptive system. This system is a combination between customary law and applicative law of the area where the society settled. Related to inheritance determination, this society tends to apply conventional law system and they leave their customary law although they still want to apply the customary one.
\end{abstract}

Salah satu hukum adat yang sangat menarik yaitu tentang penerapan hukum adat masyarakat Minangkabau yang berkaitan dengan hukum waris. Masyarakat Minangkabau menerapkan hukum waris dari garis keturunan Ibu. Hal ini sangat kontradiksi dengan sistem hukum waris Islam yang menarik keturunan dari garis ayah. Tujuan dari penelitian ini ingin mendiskripsikan pola konstruksi sosial dan sistem hukum waris yang dibangun masyarakat Minangkabau ketika menetap di Malang. Metode penelitian ini menggunakan penelitian lapangan dengan menggunakan pendekatan kualitatif deskriptif. Hasil penelitian ini, peneliti menyimpulkan bahwa konstruksi sosial yang di bangun masyarakat Minangkabau yang menetap di Malang yaitu menggunakan sistem adaptif. Dimana sistem ini merupakan suatu bentuk peleburan terhadap hukum adat dengan hukum yang berlaku di daerah mereka menetap. Dalam hal penerapan waris, masyarakat Minangkabau yang menetap di Malang mereka cenderung memakai sistem hukum konvensional, dan menanggalkan hukum adat meraka, meskipun masih ada keinginan untuk menerapkan hukum adat Minangkabau di Malang.

Kata kunci: Custom Law, Minangkabau, Inheritance Law.

Berbicara mengenai hukum waris dalam kacamata adat minangkabau merupakan masalah yang masih aktual dalam berbagai pembahasan. Hal itu mungkin disebabkan karena keunikannya bila dibandingkan dengan sistem hukum adat waris dari berbagai daerah-daerah lain di Indonesia. Sistem kekeluargaan di Mingangkabau adalah sistem yang menarik garis keturunan dari pihak ibu yang dihitung menurut garis ibu, yakni saudara laki-laki dan saudara perempuan, nenek beserta saudara-saudaranya, baik laki-laki maupun perempuan. Dengan sistem tersebut, maka semua anak-anak hanya dapat menjadi ahli waris dari ibunya sendiri, baik untuk harta pusaka tinggi yaitu harta yang turun-temurun dari beberapa generasi, maupun harta pusaka rendah, yaitu harta yang turun dari satu generasi.

Pada masyarakat adat Minangkabau, harta pusaka juga diturunkan secara kolektif kepada anggota kaum dalam garis kekerabatan yang matrilinial. Hal tersebut berbeda dengan ketentuan waris yang diatur oleh hukum Islam. Menurut ketentuan hukum Islam, harta warisan diturunkan kepada ahli waris secara individual. Dan berdasarkan sistem kekerabatannya yang bilateral, harta warisan diturunkan dari garis ayah dan ibu. Dari kedua ketentuan yang berbeda tersebut, dicoba untuk mencari pertautan yang dapat ditarik di antara keduanya. 
Bila kita kaitkan persoalan ini dengan background kaum muslim Minangkabau yang berada di Malang, akan terjadi sebuah kesenjangan ontologis sehingga menurut hipotesa peneliti akan melahirkan dualitas hukum antara keduanya. Hal ini dipicu oleh tekstualitas pemahaman ayat-ayat waris yang lebih condong pada kaum laki-laki daripada perempuan. Berdasarkan permasalahan diatas, maka fokus penelitian adalah: (1) konstruksi sosial masyarakat Minangkabau Tentang Sistem Waris, (2) pemahaman masyarakat Minangkabau yang ada di Malang tentang sistem hukum waris Islam, dan (3) metode pembagian waris masyarakat Minangkabau yang ada di Malang.

\section{Metode Penelitian}

Metode yang digunakan dalam penelitian ini adalah metode pendekatan yang bersifat yuridis empiris. penelitian dengan pendekatan yuridis empiris adalah penelitian hukum mengenai pemberlakuan ketentuan hukum normatif secara in action pada setiap peristiwa hukum tertentu yang terjadi dalam masyarakat. pemberlakukan secara in action tersebut merupakan fakta empiris dan berguna untuk mencapai tujuan yang telah ditentukan oleh Negara, pemberlakukan secara in action ini diharapkan akan berlangsung secara sempurna apabila rumusan ketentuan hukum normatif jelas dan tegas serta lengkap. ${ }^{1}$ Metode pendekatan yuridis empiris untuk menunjang keakuratan data dan mencari kejelasan mengenai Sistem Hukum Waris Minangkabau Sebuah Dualitas Hukum Antara Matrinial dan Islam (Studi Konstruksi Sosial Masyarakat Minangkabau yang Bertempat di Malang).

Penelitian ini dilakukan di Kota Malang. Sasaran penelitiannya masyarakat Minangkabau yang ada dan menetap di Malang, khususnya masyarakat Minangkabau yang berprofesi sebagai pedagang warung nasi Padang.

Untuk memperoleh data digunakan teknik pengumpulan data sebagai berikut: (a) Data primer diperoleh dengan melakukan penelitian lapangan berupa wawancara. Wawancara adalah metode pengumpulan data dengan melakukan tanya jawab secara lisan dengan informan; (b) Data sekunder, dikumpulkan melalui penelusuran perpustakaan, yaitu dengan mengumpulkan data dan menginventaris bukubuku sumber bacaan, peraturan perundang-undangan dan bahan-bahan lain yang dengan bidang ilmu hukum, khusunya yang berkaitan sistem kewarisan pada

1 Emi emilia, Menulis Tesis dan Disertasi, (Bandung : CV.Alfabeta 2008), h. 12
Masyarakat Minangkabau. Analisis data dilakukan secara kualitatif yaitu dari data yang diperoleh kemudian disusun secara sistematis dan analisa untuk mencapai kejelasan masalah yang dibahas, yang diuraikan secara kualitatif yakni mengungkap atau menggambarkan kenyataan kenyataan yang terdapat di lapangan dalam bentuk kalimat yang sistematis.

Selanjutnya, data yang telah dikumpulkan secara lengkap dan telah dicek keabsahannya dan dinyatakan valid, lalu diproses melalui langkahlangkah bersifat umum yakni :2 (a) Reduksi data adalah data yang diperoleh di lapangan ditulis atau diketik dalam bentuk uraian atau laporan yang terinci. Laporan tersebut direduksi, dirangkum, dipilih hal-hal yang pokok, difokuskan pada hal-hal yang penting, dicari tema dan polanya. (b) Mengambil kesimpulan dan Verifikasi, yaitu data yang telah terkumpul telah direduksi, lalu berusaha untuk mencari maknanya, kemudian mencari pola, hubungan, persamaan, halhal yang sering timbul dan kemudian disimpulkan.

\section{Hasil dan Pembahasan}

\section{Terminologi Waris Islam dan Waris Adat}

Waris dalam Islam disebut dengan istilah alfarai-dh yang merupakan bentuk jamak dari kata alfaridhah. Sedangkan kata faraidh itu sendiri diambil dari kata al-fardhu yang maknannya adalah al-taqdiir yang berarti ketentuan.

Waris berasal dari bahasa Arab, yaitu bentuk jamak dari kata mirats, ${ }^{3}$ yang mempunyai maksud makna harta peninggalan yang ditinggalakan oleh simati dan diwarisi oleh ahli warisnya. ${ }^{4}$ Dan kata waris dalam al-Quran dibahas sebanyak 23 ayat, ${ }^{5}$ diantaranya ayat yang dijadikan dasar dalam pembahasan waris adalah: surat an-Nisa (4): 11 yang artinya:

"Allah mensyari'atkan bagimu tentang (pembagian pusaka untuk) anak-anakmu. Yaitu : bahagian seorang anak lelaki sama dengan bagahian dua orang anak perempuan; dan jika anak itu semuanya perempuan lebih dari dua, maka bagi mereka dua pertiga dari harta yang ditinggalkan; jika anak perempuan itu seorang saja, maka ia memperoleh separo harta. Dan untuk dua orang ibu-bapa, bagi masing-masingnya seperenam dari harta yang ditinggalkan, jika yang

2 Roony Hanitijo soemitro, Metode Penelitian Hukum dan Yurimetri, (Ghaila Indonesia, 1984) h. 45

3 Suparman Usman dan Yusuf Somawinata, Fiqh Mawaris (Jakarta:Gaya Media Pratama, 1997), h. 13

4 Suparman Usman, Fiqh Mawaris, h. 14

5 Muhammad Fu'ad Abdul Baqy, Al Mu'jam Al Mufahros Lil Al Fadhil Al Qur'an( Bandung: Diponegoro, 1945) 
meninggal itu mempunyai anak; jika orang yang meninggal tidak mempunyai anak dan ia diwarisi oleh ibu-bapanya (saja), maka ibunya mendapat sepertiga; jikayang meninggalitumempunyaibeberapa saudara, maka ibunya mendapat seperenam. (Pembagianpembagian tersebut di atas) sesudah dipenuhi wasiat yang ia buat atau (dan) sesudah dibayar hutangnya. (Tentang) orang tuamu dan anak-anakmu, kamu tidak mengetahui siapa di antara mereka yang lebih dekat (banyak) manfaatnya bagimu. Ini adalah ketetapan dari Allah. Sesungguhnya Allah Maha Mengetahui lagi Maha Bijaksana".

Adapun ayat-ayat lain terdapat dalam surat anNisa: 7, 12, 33, 176, dan masih banyak lagi ayat -ayat yang menjelaskan tentang waris yang tersebar dalam surat al-Baqorah, al-Anfal, dan al-Ahzab. ${ }^{6}$

Sedangkan orang-orang yang dapat menerima warisan ada tiga golongan yaitu dzuu fardhin ( ahli waris yang mempunyai bagian yang pasti), ashobah ( ahli waris yang tidak mendapatkan bagian tertentu), dan rahim (kerabat). Dan bagian dari golongan dzuu fardhi dalam kitabullah ada enam yaitu setengah, sepertiga, dua pertiga, seperempat, seperenam, dan seperdelapan. ${ }^{7}$ Ketiga golongan tersebut terbagi menjadi 25 orang, yang terdiri dari 15 orang dari pihak laki-laki dan 10 orang dari pihak perempuan. ${ }^{8}$ Dan didalam hukum Islam asas yang dipakai dalam pembagian waris ada lima, yaitu: asas Ijbari, asas bilateral, asas individual, asas keadilan, dan asas sebab kematian. ${ }^{9}$ Dimana dalam prosesi pembagian waris kelima asas ini harus ada dan jika salah satu tidak ada maka pembagian warisnya disebut pembagian waris yang bathil.

Kata adat adalah istilah yang dikutip dari bahasa Arab tetapi telah diterima dalam semua bahasa di Indonesia yang berarti kebiasaan ${ }^{10}$ Sedangkan definisi hukum adat secara terminologi, beberapa tokoh hukum adat mengemukakan pendapatnya mengenai pengertian dari hukum adat antara lain : Van Vollenhoven mengatakan Hukum Adat adalah hukum adat yang tidak bersumber kepada peraturan-peraturan yang dibuat oleh Pemerintah Hindia Belanda dahulu

6 Abdul Ghafur Anshari, Filsafat Hukum Waris Islam ( Yogyakarta: UIN Pres, 2005), h. 20-25

7 Abdul Azhim bin Badhawi Al-Kholafi, h. 697.

8 Sulaiman Rasjid, Fikih Islam ( Cet. 45, Bandung: Sinar Baru Algensindo, 2010), h. 349.

9 Amir Syarifuddin, Hukum Kewarisan Islam ( Cet. III, Jakarta: Kencana, 2008), h. 17-28

10 Ahmad Kunaifi, Kedudukan dan Peran Laki-laki dalam Masyarakat Minangkabau Bukittinggi Perantauan di Jakarta Pengaruh Terhadap Hukum, Tesis Magister Kenotariatan ( Semarang: Universitas Diponegoro, 2005), h. 23 atau alat-alat kekuasaan lainnya yang menjadi dan diadakan sendiri oleh kekuasaan Belanda dahulu. ${ }^{11}$

Ter Haar memaparkan Hukum adat adalah keseluruhan peraturan yang menjelma dalam keputusankeputusan para fungsionaris hukum (dalam arti luas) yang mempunyai wibawa (macht authority) serta pengaruh dan yang dalam pelaksanaannya berlaku serta merta dan dipatuhi dengan sepenuh hati" ${ }^{12}$ Sedangkan Soepomo menguraikan Hukum adat adalah sebagai hukum adat yang tidak tertulis di dalam peraturan-peraturan legislative (unstatiry law) meliputi peraturan-peraturan hidup yang meskipun tidak ditetapkan oleh yang berkewajiban ditaati dan didukung oleh rakyat berdasarkan atas keyakinan bahwasan peraturan-peraturan tersebut mempunyai kekuatan hukum. ${ }^{13}$

Paparan Hazairin mengenai Hukum adat adalah resapan (endapan) kesusilaan dalam masyarakat, yaitu bahwa kaidah-kaidah adat itu berupa kaidahkaidah kesusilaan yang sebenarnya telah mendapat pengakuan umum dalam masyarakat. ${ }^{14}$ Sukanto juga mengemukakan bahwa Hukum adat sebagai kompleks adat-adat yang kebanyakan tidak dikitabkan, tidak dikodifikasi dan bersifat paksaan mempunyai sanksi jadi mempunyai akibat hukum." ${ }^{15}$

Pada hakekatnya tahun 1893 Snouck Hurgronje sudah memperkenalkan istilah hukum adat sebagai nama untuk menyatakan hukum rakyat Indonesia yang tidak dikodifikasi. Menurut Snouck Hurgronje hukum adat merupakan suatu kebiasaan yang berlaku pada masyarakat yang berbentuk peraturan yang tidak tertulis. $^{16}$

\section{Sistem Hukum Adat Waris Minangkabau}

Adapun yang dimaksud adat di Minangkabau adalah adat yang tidak lekang dipanas, tidak lapuk dihujan, yaitu adat ciptaan Tuhan Yang Maha Pencipta. ${ }^{17}$ Sebagaimana dikatakan dalam pepatah adat Minangkabau : ikan adatnya beradai, air adanya membasahi, pisau adatnya melukai, artinya adat yang dimaksud di sini adalah perilaku alamiah yang hidup ditengah-tengah masyarakat sehingga menjadi ketetapan yang tidak berubah. Jadi hukum adat

\footnotetext{
11 Van Vollenhoven, Penemuan Hukum Adat, (Jakarta : Djambatan 1987), h. 6 12 Imam Sudiyat, Azas-azas Hukum Adat (Liberty Yogyakarta, 1985)

13 Soepomo, Bab-bab Tentang Hukum Adat (Bandung: University, 1989), h. 13

14 Hilman Hadikusuma, Pokok-pokok Pengertian Hukum Adat (Bandung: Alumni Bandung, 1980 )

15 Sukanto, Meninjau Hukum Adat, (Jakarta: Gunung Agung, 2001)

16 A. Soehardi, Pengantar Hukum Adat Indonesia, N.V Penerbitan W Van Hoeve, (Bandung : S-Gravenhage,1954), h. 45

17 Chairil Anwar, Hukum Adat Indonesia (Meminjam Hukum Adat Minangkabau), (Jakarta : Rineka Cipta), h. 10.
} 
Minangkabau adalah kebiasaan-kebiasaan yang telah lama berlangsung dalam masyarakat yang menjadi ketentuan-ketentuan dasar sebagai aturan (kaidah) ditentukan oleh nenek moyang (leluhur) yang berada di Minangkabau dikatakan berasal dari Datuk Katemanggungan dan Datuk Perpatihan Nan Sebatang di balai Balairung Padang Panjang.

Masyarakat Minangkabau dalam tatanan sosialnya memakai prinsip keturunan matrilineal, artinya menghitung garis keturunan dari pihak ibu, sehingga seorang anak akan menjadi anggota suku ibunya. Dengan prinsip keturunan matrilineal ini unsur Paman (saudara laki-laki ibu) menjadi tokoh yang sangat penting. Ia memikul tanggung jawab yang berat karena baik-buruknya keadaan kemenakan (anak saudara perempuannya) berada sepenuhnya ditangan Paman (mamak dalam bahasa minangkabau). Ini disebabkan karena walaupun yang punya anak adalah ibu, namun fungsi ayah dalam keluarga suku bangsa Minangkabau hanyalah sebagai tamu di rumah isterinya (disebut urang sumando). Urang Sumando ini tidak memiliki kekuasaan di rumah isterinya. Karena kekuasaan nya berada dalam lingkungan keluarga ibunya pula.

Dalam permasalahan waris, masyarakat minangkabau memakai sistem dualitas, yang merupakan manifestasi dari sistem waris adat dan Islam. Adapun yang dimaksud dengan hukum waris adat merupakan peninggalan dari nenek moyang yang secara turun temurun diteruskan oleh para keturunannya. Dimana antara masyarakat adat yang satu dengan masyarakat lainnya mempunyai kebisaan yang tidak sama tentang ketentuan hukum waris adat. Hukum waris adat sesungguhnya adalah hukum penerusan harta kekayaan dari suatu generasi kepada keturunannya. Dalam hal ini pendapat para ahli hukum adat tentang pengertian hukum waris adat antara lain :

Ter Haar mengatakan Hukum waris adat adalah aturan-aturan yang mengenai cara bagaimana dari abad ke abad penerusan dan peralihan dari harta kekayaan yang berujud dan tidak berujud dari generasi ke generasi. ${ }^{18}$ Sedangkan Soepomo menjelaskan Hukum waris adat adalah peraturan-peraturan yang mengatur proses meneruskan serta mengoperkan barang-barang harta benda dan barang-barang yang tidak berwujut benda (inmaterialle goederen) dari suatu angkatan manusia dari generasi kepada keturunannya." 19

Imam Sudiyat mencoba menguraikan bahwa Hukum waris adat meliputi aturan-aturan dan ke-

\footnotetext{
18 Hilman Hadikusuma, Hukum Waris Adat ( Bandung: Citra Aditya Bakti, 2003 )

19 Soepomo, Op. Cit., h. 122.
}

putusan hukum yang bertalian dengan proses penerusan atau pengoperan dan peralihan atau perpindahan harta kekayaan material dan non material dari generasi ke generasi. ${ }^{20}$ Dan Wirjono Prodjodikoro, bahwa warisan itu adalah soal apakah dan bagaimanakah berbagai hak dan kewajibankewajiban tentang kekayaan seseorang pada waktu dia meninggal dunia akan beralih pada lain yang masih hidup. ${ }^{21}$

Dengan demikian para ahli hukum adat tersebut mendefinisikan bahwa hukum waris adat memuat ketentuan-ketentuan yang mengatur cara penerusan dan peralihan harta kekayaan. Dan cara penerusan dan peralihan harta kekayan itu berlaku sejak pewaris masih hidup atau pewaris sudah meninggal.

Adapun sistem waris masyarakat Minangkabau menganut sistem kewarisan secara kolektif, yaitu sistem kewarisan, dimana harta peninggalan sebagai keseluruhan dan tidak terbagi-bagi dimiliki secara bersama-sama oleh para pihak ahli waris seperti : harta pusaka tinggi yaitu harta pusaka yang dimiliki secara bersama-sama oleh kekerabatan yang turun temurun. Sedangkan harta pusaka rendah adalah harta yang diturunkan oleh seorang ibu kepada anak-anak perempuannya yang pemiliknya tidak dibagi-bagikan secara individu tetapi dinikmati bersama-sama yang mana lama kelamaan akan menjadi pula harta pusaka tinggi.

Secara psikiologis pada masyarakat Minangkabau memiliki hubungan dengan peraturan adatnya tersebut. Menurut adat kepercayaan ketentuan-ketentuan adat mengenai harta warisan haruslah ditaati.

Mereka memiliki kepercayaan bahwa arwah leluhur yang wafat tetap berhubungan dengan para anggota suku yang memberikan hukuman (sanksi), memberikan hukum adat dan memberikan anugerah. Maka peraturan adat ditaati dan tidak diabaikan.

\section{Teori Konstruksi Sosial}

Konstruksi sosial merupakan suatu bentuk teori formal dalam sebuah penelitian pada sebuah fokus Sistem Hukum Waris Minangkabau : Sebuah Dualitas Hukum Antara Matrialinial dan Islam (Studi Konstruksi Sosial Masyarakat Minangkabau yang Menetap di Malang ). Teori konstruksi sosial dalam gagasan Berger ${ }^{22}$ mengatakan bahwa agama sebagai

\footnotetext{
20 I.G.N. Sugangga, Hukum Waris Adat, (Semarang : Universitas Diponegoro, 1995)

21 Hilman Hadikusuma, Op. Cit., h. 8

22 Peter L. Berger \& Thomas Luchman, Tafsir sosial Atas Kenyataan: Risalah Tentang Sosiologi Pengetahuan ( Jakarta: LP3ES, 1990). Lihat pulan Peter L. Berger. The Sacret Canopy: Elemens of a Sosiological Theory of Relegion. (New York: Anchor Books, 1967), h. 33-36
} 
bagian dari kebudayaan, merupakan konstruksi manusia. Hal itu dapat di artikan bahwa dalam kehidupan bermasyarakat terdapat proses dialetika ketika melihat hubungan masyarakat dengan agama, bahwa agama merupakan entitas yang objektif karena berada diluar diri manusia. Dengan demikian agama melalui proses obyektivitas, seperti agama berada didalam teks atau menjadi tata nilai, norma aturan, dan sebagainya. Teks atau norma tersebut mengalami internalisasi kedalam diri individu sebab agama telah diinterpretasikan oleh masyarakat untuk menjadi pedomannya. Agama juga mengalami proses eksternalisasi karena agama juga menjadi suatu yang shared di masyarakat. Agama kemudian menjadi acuan norma yang berfungsi menuntun dan mengkontrol tindakan masyarakat.

Manusia yang hidup dalam konteks tertentu, melakukan interaksi secara simultan dengan lingkungannya. Masyarakat hidup dalam dimensi-dimensi dan realitas objektif yang dikonstruksi melalui momen internalisasi dan objektivitasi dan dimensi subjektif yang dibangun melalui momen internalisasi. Momen eksternalisasi, objektivasi, dan internalisasi tersebut akan selalu berproses dalam masyarakat secara dialektis. ${ }^{23}$ Dengan demikian yang dinamakan kenyataan sosial, sesungguhnya merupakan hasil dari sebuah konstruksi sosial karena diciptakan manusia itu sendiri. Dalam konteks ini, Sistem Hukum Waris Minangkabau : Sebuah Dualitas Hukum antara Matrialinial dan Islam merupakan sebuah ketetapan hukum yang berlaku dimasyarakat dan dianggap sebagai fikih konteks Indonesia, dikonstruksi oleh situasi dan kondisi yang dibangun oleh masyarakat Minangkabau.

Proses dialektika ketiga momen tersebut dalam konteks penelitian ini, dapat di pahami sebagai berikut: Pertama, Proses eksternalisasi, dimana proses ini mengatakan bahwa manusia merupakan sosok mahluk hidup yang senantiasa berdialektika dengan lingkungan sosialnya secara simultan. Eksternalisasi merupakan momen dimana seseorang melalukan adaptasi diri terhadap lingkungan sosialnya. Dunia sosialnya kendati merupakan hasil dari aktifitas manusia, namun ia mengharapkan dirinya sebagai sesuatu yang bersifat eksternal bagi manusia sesuatu yang berada di luar diri manusia.

Realitas dunia sosial yang mengejawatah, merupakan pengalaman hidup yang bisa dijadikan sebagai dasar seseorang untuk membentuk pengetahuan atau mengkonstruk sesuatu. Realitas sosial juga mengharuskan seseorang untuk memberikan responnya. Respon tersebut bisa berupa penerimaan, penyesuaian, maupun penolakan. Bahasa dan tindakan merupakan sarana seseorang untuk mengkonstruk dunia sosio-kulturalnya melalui momen eksternalisasi ini. Secara sederhana bisa di pahami bahwa, momen eksternalisasi merupakan proses visualisasi pikiran dari dimensi batiniah ke dimensi lahiriah. Eksternalisasi merupakan proses pengeluaran gagasan dari dunia ideke dunia nyata.

Kedua, Proses objektivasi, merupakan momen intraksi antara dua realitas yang terpisahkan satu sama lainnya. Manusia di satu sisi dan realitas sosio kultural di pihak lain. kedua entitas yang seolah terpisah ini kemudian membentuk jaringan intraksi intersubjektif. Momen objektivisi merupakan momen hasil dari kenyataan eksternalisasi yang kemudian mengejawantah sebagai sebuah kenyaataan objektif yang sui generis.

Dalam konteks ini, objektivasi dalam pemahaman bergerian merupakan sebuah upaya memberikan makna baru yang di konstruk para masyarakat Minangkabau. Dengan demikian, proses objektivasi merupakan langkah peneliti dalam memberikan penjelasan dan pemaknaan terhadap konstruksi sosial yang telah yang telah dieksternalisasi oleh masyarakat Minangkabau.

Ketiga, Proses internalisasi, momen ini merupakan suatu momen penarikan realitas sosial-kultural kedalam diri atau penarikan realitas sosial-kultural ke dalam realitas subjektif. Hasil dari objektivasi tersebut di batinkan kembali sehingga mengkonstruk pada dunia pikiran manusia. Kenyataan-kenyataan objektif yang mendasari konstruk masyarakat Minangkabau ( perang invansi fisik, perang kulturalsemiotik, perang pikiran, konspirasi dan sebagainya) dan diinternalisasi dalam gerakan, sehingga menjadi kenyataan yang objektif dalam gerakan tersebut.

Adapun gambaran mengenai kerangka teoritik pada rumusan masalah di atas sebagai berikut: 


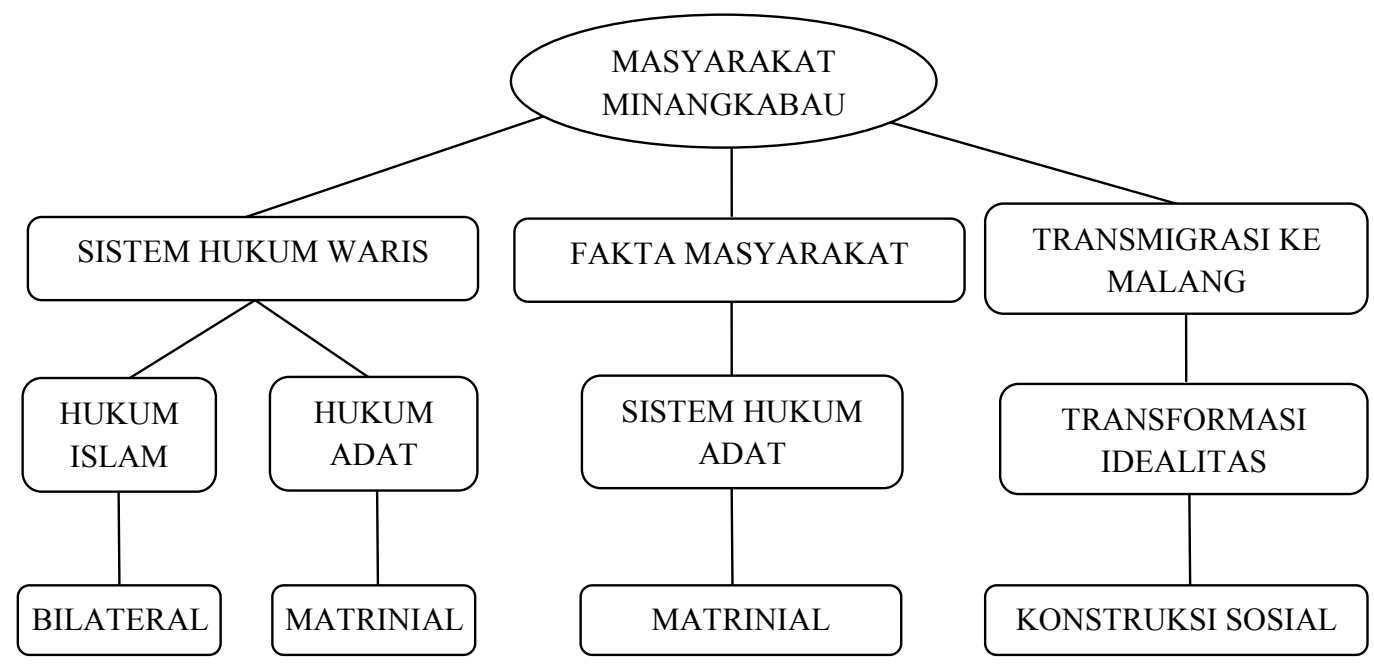

Dalam paparan data ini, terdapat dua data emik, yaitu pandangan masyarakat Minangkabau terhadap sistem hukum waris Islam dan model pembagian sistem waris Masyarakat Minangkabau ketika migrasi ke Malang. Dan penjelasannya dapat saya uraikan sebagai berikut :

Data Emik Pandangan Masyarakat Minangkabau Terhadap sistem Kewarisan Menurut Islam. Pertama, A. DT. Tan Pahlawan ( Pimpinan Himpunan Masyarakat Minang Taboh Gadang ( HIMATOS) ) "Ketika saya bertanya tentang sistem kewarisan menurut Islam, Datok A. DT. Tan Pahlawan dengan wajah priyangnya mengatakan bahwa, mayoritas masyarakat minangkabau menganut agama Islam. Tetapi dalam kaitannya dengan pembagian waris masyarakat minang lebih mengedepannya sistem kewarisan adat (matrinial) daripada memakai sistem kewarisan Islam itu sendiri. Hal ini sudah dilakukan sebagai wujud penghormatan kepada nenek-moyang kami. Kedua, P. Handara ( seorang pegawai warung masakan Padang) Dengan pertanyaan yang sama, Pak Hendra mengatakan bahwa dia kurang memahami tentang sistem kewarisan Islam, meskipun dia sendiri seorang muslim. Menurut dia hal ini disebabkan begitu kentalnya budaya adat masyarakat setempat.

Ketiga, Pak Zainul Efendi ( Pemilik Warung Padang) Dengan model pertannyaan yang sama, Pak Zainul Efendi mengatakan bahwa dia juga kurang memahami sistem kewarisan Islam, sehingga dalam hal ini dia tidak berkomentar. Keempat, Pak Ariel ( seorang pemilik warung Padang) Dalam kaitannya sistem kewarisan Islam, Pak Ariel mengatakan bahwa mayoritas masyarakat Minang adalah muslim. Dan dalam hal sistem kewarisan Islam dia mengetahui meskipun tidak begitu mendalam. Dan menurut pandangannya sistem kewarisan Islam itu bagus, tetapi dia tidak dapat mengelak dari sistem kewarisan adat karena sistem kewarisan adat ini sudah membelenggu dalam jiwa mereka. Sehingga dalam hal pembagian waris dan mereka lebih condong memakai sistem kewarisan adat dari pada sistem kewarisan agama yang dianut oleh masyarakat Minangkabau.

Kelima, Andi (Seorang Mahasiswa UIN Malang) Dengan model pertannyaan yang sama juga, mahasiswa ini dengan lagak polosnya mengatakan bahwa dia kurang tau dengan sistem kewarisan Islam.

Bagaimana sistem pembagian waris masyarakat Minangkabau yang ada di Malang? Pertama, menurut A. DT. Tan Pahlawan Datok ini mengatakan bahwa" ketika kami merantau atau migrasi ke malang kami melepaskan sistem kewarisan adat kami. Dan kami ketika di sini, sistem kewarisan yang kami pakai adalah sistem waris masyarakat Malang. Karena sistem kewarisan adat yang ada di Minangkabau sifatnya adalah harta pusaka yang sifatnya sudah turun-temurun dari nenek moyang kami. Dan ketika kami di Malang hal seperti tersebut, kami belum mempunyainya, sehingga harta kami adalah karta anak-anak kami tidak ada perbedaan pembagian dalam hal kewarisan baik anak laki-laki atau anak perempuan. Kedua, Pak Zainul Efendi mengatakan bahwa" ketika kami berada di malang kami menggunakan sistem kewarisan yang ada di Malang, yaitu sistem bagi rata kepada anak-anak kami tanpa ada perbedaan diantara mereka. Ketika saya perdalam pertanyaannya terkait mengapa tidak memakai sistem kewarisan adat yang ada di Minangkabau? Dia menjawab bahwa" kami disini 
tidak punya harta warisan tinggi mas, dan kami hanya mempunyai harta warisan rendah, dan harta warisan rendah inilah yang kami wariskan kepada anak-anak kami."

Ketiga, P. Handara Berkaitan tentang permasalahan di atas, beliau mengatakan bahwa" ketika kami berada di Malang kamimenggunakan sistem kewarisan adat Malang, yaitu bagi rata kepada anak-anak kami. Hal ini kami lakukan sebagai bentuk atau wujud penghormatan kepada masyarakat adat, meskipun dalam benak kami masyarakat Minangkabau ingin menerapkan sistem kewarisan adat kami. Keempat, Pak Ariel juga mengatakan kepada kami, berkaitan dengan sistem kewarisan yang di bangun di Malang bahwa" kami ketika merantau kemalang sistem kewarisan yang kami pakai adalah sistem kewarisan bagirata kepada ahli waris kami, hal ini kami lakukan karena usaha yang kami lakukan adalah usaha kami sendiri, gak ada intervensi dari keluarga adat. Sehingga harta yang kami kumpulkan hanya untuk anak keturunan kami saja dengan sistem bagi rata.

Kelima, Andi Dalam hal waris Andi mengatakan bahwa" sistem kewarisan yang di bangun di Malang adalah sistem bagi rata, tidak ada perbedaan bagian antara anak laki-laki maupun perempuan. Karena masyarakat Minangkabau yang ada di Malang jumlahnya hanya minoritas. Lalu saya perdalam lagi pertanyaannya jika masyarakat Minangkabau jumlahnya mayoritas? Lalu dia mengatakan tergantung keadaanya, apabila sama-sama keturunan minang bisa di lakukan dan hal itu pun tergantung kesepakatan mereka berdua.

\section{Konstruksi sosial masyarakat Minangkabau di Malang.}

Adapun sistem konstruksi sosial masyarakat Minang yang dibangun di Malang yaitu sistem adaptif. Dimana sistem ini, merupakan sistem peleburan terhadap adat lama dengan melakukan adaptasi dengan budaya yang baru. Akan tetepi tidak secara totalitas mereka melakukan peleburan secara menyeluruh, melainkan nilai-nilai adat lama masih termaktup dalam konstruk pemikiran dan prilaku mereka. Mereka membuat suatu himpunan masyarakat Minang Taboh Gadang yang di singkat dengan HIMATOS. ${ }^{24}$ Dimana HIMATOS ini, dijadikan sebagai tempat perkumpulan dan juga pusat informasi masyarakat Minang yang ada di Malang.

24 Wawancara dengan A. DT. Tan Pahlawan pada tanggal : 09-04-2012
Adapun jumlah masyarakat Minang yang ada di Malang kurang lebih dari seratus kepala keluarga. Dan mayoritas mereka di malang berprofesi sebagai Pedagang, dosen, mahasiswa dan lain-lain. ${ }^{25}$

Dalam sejarah kita mengetahui bahwa Agama Islam telah lama masuk ke dalam lingkungan adat Minangkabau. Dalam perkembangannya secara bertahap ajaran Islam telah banyak merubah dan menyempurnakan tata susunan adat lama. Islam telah memperkenalkan susunan kekeluargaan baru dalam bentuk keluarga inti pada masa sekarang ini sudah meluas dikalangan masyarakat Minangkabau pada umumnya.

Selain itu agama Islam membawa ajaran tentang hidup berkeluarga dan tanggung jawab terhadap keluarga. Ajaran itu berbeda dengan ajaran adat sebelumnya, dimana menurut adat seorang anak hanya berhubungan dengan ibunya saja sedangkan menurut Islam hubungan itu juga temasuk dengan ayahnya. Seorang ayah atau suami wajib untuk membiayai kehidupan istri dan anak-anaknya dalam ajaran Islam, hal ini menunjukkan bahwa adanya hubungan timbal balik antara ayah dengan anak-anaknya. Dengan demikian terlihat bahwa ajaran Islam telah membawa pengaruh yang kuat dari hubungan kerabat mamak (kepala waris) kepada kemenakan yang merupakan salah satu ciri kekerabatan materilineal menjadi hubungan antara anak, ayah, ibu, dan mamak (kepala waris), namun bentuk keluarga besar yang merupakan ciri adat lama masih terdapat pada masyarakat Minangkabau.

Akan tatapi realitas di lapangan membuktikan bahwa masyarakat Minangkabau meskipun mayoritas menganut agama Islam. Pola kebudayaan mereka tidak berubah. Mereka tetap mempertahankan budaya lokalnya secara turun-temurun, kalau dalam waris kita mengenal sistem waris matrinial. Sebagaimana Pak Ariel ketika di tanya pandangannya terhadap sistem kewarisan Islam, Pak Ariel mengatakan bahwa "mayoritas masyarakat Minang adalah muslim. Dan dalam hal sistem kewarisan Islam dia mengetahui meskipun tidak begitu mendalam. Dan menurut pandangannya sistem kewarisan Islam itu bagus, tetapi dia tidak dapat mengelak dari sistem kewarisan adat karena sistem kewarisan adat ini sudah membelenggu dalam jiwa mereka. Sehingga dalam hal pembagian waris dan mereka lebih condong memakai sistem kewarisan adat dari pada sistem kewarisan agama yang dianut oleh masyarakat Minangkabau." 26

25 Wawancara dengan A. DT. Tan Pahlawan pada tanggal : 09-04-2012 26 Wawancara dengan Ariel pada tanggal 11-04-2012 
Hal ini pun di perkuat oleh pendapatnya Pak Hendra, dengan pertanyaan yang sama, Pak Hendra mengatakan bahwa" dia kurang memahami tentang sistem kewarisan Islam, meskipun dia sendiri seorang muslim. Menurut dia hal ini disebabkan begitu kentalnya budaya adat masyarakat setempat." ${ }^{27}$

Hal ini selaras dengan teori konstruksi sosial dalam gagasan Berger ${ }^{28}$ yang mengatakan bahwa agama sebagai bagian dari kebudayaan, merupakan konstruksi manusia. Hal itu dapat di artikan bahwa dalam kehidupan bermasyarakat terdapat proses dialektika ketika melihat hubungan masyarakat dengan agama, bahwa agama merupakan entintas yang objektif karena berada diluar diri manusia. Dengan demikian agama melalui proses obyektivitas, seperti agama berada didalam teks atau menjadi tata nilai, norma aturan, dan sebagainya. Teks atau norma tersebut mengalami internalisasi kedalam diri individu sebab agama telah diinterpretasikan oleh masyarakat untuk menjadi pedomannya. Agama juga mengalami proses eksternalisasi karena agama juga menjadi suatu yang shared di masyarakat. Agama kemudian menjadi acuan norma yang berfungsi menuntun dan mengkontrol tindakan masyarakat.

Sehingga dalam uraian diatas, secara garis besar masyarakat Minang tidak memahami tentang sistem pembagian sistem hukum waris yang ada dalam Islam. Hal ini di sebabkan oleh begitu kentalnya hukum adat yang berlaku didaerahnya. Karena hukum adat merupakan pola dasar dalam paradikma yang sudah disakralisasi oleh masyarakat. Dengan demikian yang dinamakan kenyataan sosial, sesungguhnya merupakan hasil dari sebuah konstruksi sosial karena diciptakan manusia itu sendiri. Dalam konteks ini, Sistem Hukum Waris Minangkabau : Sebuah Dualitas Hukum antara Matrialinial dan Islam merupakan sebuah ketetapan hukum yang berlaku dimasyarakat dan dianggap sebagai fikih konteks Indonesia, dikonstruksi oleh situasi dan kondisi yang dibangun oleh masyarakat Minangkabau.

\section{Metode pembagian waris masyarakat Minang- kabau di Malang}

Minangkabau atau yang biasa disingkat Minang adalah kelompok etnik Nusantara yang berbahasa dan menjunjung adat Minangkabau. Wilayah penganut kebudayaannya meliputi Sumatera Barat, separuh daratan Riau, bagian utara Bengkulu, bagian barat Jambi, pantai barat Sumatera Utara, barat daya Aceh,

27 Wawancara dengan Hendra pada tanggal 11-04-2012

28 Peter L. Berger \& Thomas Luchman, op.cit., h. 33-36. dan juga Negeri Sembilan di Malaysia. ${ }^{29}$ Dalam percakapan awam, orang Minang seringkali disamakan sebagai orang Padang, merujuk kepada nama ibukota provinsi Sumatera Barat yaitu kota Padang. Namun, masyarakat ini biasanya akan menyebut kelompoknya dengan sebutan urang awak (bermaksud sama dengan orang Minang itu sendiri).

Dalam kaitannya dengan hukum waris, masyarakat Minangkabau memakai sistem hukum adat yaitu sistem Matrilineal. Dimana sistem ini, merupakan salah satu aspek utama dalam mendefinisikan identitas masyarakat Minang. Adat dan budaya mereka menempatkan pihak perempuan bertindak sebagai pewaris harta pusaka dan kekerabatan. Garis keturunan dirujuk kepada ibu yang dikenal dengan Samande (se-ibu). Sedangkan ayah mereka disebut oleh masyarakat dengan nama Sumando (ipar) dan diperlakukan sebagai tamu dalam keluarga.

Kaum perempuan di Minangkabau memiliki kedudukan yang istimewa sehingga dijuluki dengan Bundo Kanduang, memainkan peranan dalam menentukan keberhasilan pelaksanaan keputusan-keputusan yang dibuat oleh kaum lelaki dalam posisi mereka sebagai mamak (paman atau saudara dari pihak ibu), dan penghulu (kepala suku). Pengaruh yang besar tersebut menjadikan perempuan Minang disimbolkan sebagai Limpapeh Rumah nan Gadang (pilar utama rumah). Walau kekuasaan sangat dipengaruhi oleh penguasaan terhadap aset ekonomi namun kaum lelaki dari keluarga pihak perempuan tersebut masih tetap memegang otoritas atau memiliki legitimasi kekuasaan pada komunitasnya.

Matrilineal tetap dipertahankan masyarakat Minangkabau sampai sekarang walau hanya diajarkan secara turun temurun dan tidak ada sanksi adat yang diberikan kepada yang tidak menjalankan sistem kekerabatan tersebut. Pada setiap individu Minang misalnya, memiliki kecenderungan untuk menyerahkan harta pusaka yang seharusnya dibagi kepada setiap anak menurut hukum faraidh dalam Islam hanya kepada anak perempuannya. Anak perempuan itu nanti menyerahkan pula kepada anak perempuannya pula. Begitu seterusnya. Sehingga Tsuyoshi Kato dalam disertasinya menyebutkan bahwa sistem matrilineal akan semakin menguat dalam diri orang-orang Minangkabau walau mereka telah menetap di kota-kota di luar Minang sekalipun dan mulai mengenal sistem patrilineal. ${ }^{30}$

\footnotetext{
29 Josselin de Jong, P.E. de, Minangkabau and Negeri Sembilan: SocioPolitical Structure in Indonesia( Jakarta: Bhartara, 1960)

30 Tsuyoshi Kato, Adat Minangkabau dan merantau dalam perspektif sejarah. ( Jakarta: PT Balai Pustaka, 2005)
} 
Akan tetapi ketika masyarakat minangkabau dalam perantauan, mereka tidak lagi mempertahankan sistem pembagian waris dari garis keturunan ibu. Melainkan mereka menggunakan hukum waris yang berlaku pada daerah yang mereka tempati (hukum konvensional).

Sehingga penerapan hukum waris masyarakat Minangkabau yang menetap di Malang mereka tidak lagi mempertahankan hukum adatnya, melainkan menggunakan hukum waris konvensional. Meskipun masih ada tendensi untuk melakukan penerapan hukum adat minangkabau. Sebagaimana Andi (mahasiswa) mengatakan bahwa" sistem kewarisan yang di bangun di malang adalah sistem bagi rata, tidak ada perbedaan bagian antara anak laki-laki maupun perempuan. Karana masyarakat Minangkabau yang ada di Malang jumlahnya hanya minoritas. Lalu saya perdalam lagi pertanyaannya jika masyarakat Minangkabau jumlahnya mayoritas? Lalu dia mengatakan terkadung keadaanya, apabila samasama keturunan minang bisa di lakukan dan hal itu pun tergantung kesepakatan mereka berdua.

Sehingga dari kacamata penulis mengidentifikasi bahwa masyarakat Minang pada hakekatnya ketika dalam perantauan mereka tidak lagi menggunakan hukum waris adat matrinial, melainkan menyesuaikan dengan hukum waris konvensional. Kesimpulan

Berdasarkan hasil peenelitian yang telah dilakukan, baik secara teoritis maupun empiris. Maka dapat di simpulkan bahwa Dualitas Hukum Waris Minangkabau dan Islam (Studi Kontruksi Sosial

\section{DAFTAR PUSTAKA}

Anwar, Chairil. Hukum Adat Indonesia (Meminjam Hukum Adat Minangkabau), Jakarta:Rineka Cipta.

de Jong, P.E. de, Josselin. Minangkabau and Negeri Sembilan: Socio-Political Structure in Indonesia. Jakarta: Bhartara, 1960.

emilia, Emi. Menulis Tesis dan Disertasi. Bandung : CV.Alfabeta, 2008.

Fu'ad Abdul Baqy, Muhammad. .Al Mu'jam Al Mufahros Lil Al Fadhil Al Qur'an. Bandung: Diponegoro, 1945.

Ghafur Anshari, Abdul. Filsafat Hukum Waris Islam. Yogyakarta: UIN Press, 2005.

Hadikusuma, Hilman. Hukum Waris Adat. Bandung: Citra Aditya Bakti, 2003.

Hanitijo soemitro, Roony. Metode Penelitian Hukum
Masyarakat Muslim Minangkabau Yang Menetap Di Malang) sabagai berikut: (a) Sistem kontruksi sosial yang bangun di Malang adalah suatu bentuk kontruksi peleburan terhadap adat asal daerah dengan beradaptasi dengan lingkungan yang berada di Malang. Dan dalam hal ini mereka tidak semertamerta langsung meninggalkan semua, tetapi mereka juga membuat wadah perhimpunan masyarakat Minangkabauyang bernamaHIMATOS sebagai sarana trasformasi informasi dan komunikasi. (b) Mayoritas masyarakat Minangkabau yang bertempat di Malang beragama Islam. Dan dalam hal pengetahuan tentang hukum waris Islam mereka kurang memahaminya, dikarenakan kurangnya aplikasi dari hukum waris Islam dalam lingkungannya. (c) Adapun mekanisme dalam pembagian waris yang di gunakan masyarakat minangkabau yang menetap di Malang yaitu di sesuaikan dengan hukum adat yang berlaku di Malang yaitu menggunakan hukum konvensional.

\section{Saran}

Sebagai penutup dari pembahasan ini, peneliti dapat mengemukakan dan merekomendasikan saran kepada masyarakat Minangkabau. Kita sebagai umat Islam setidaknya harus memahami dan mengetahui sitem hukum waris Islam, meskipun tidak mengaplikasikanya dalam lingkungannya. Karena dalam Islam mempelajari hukum waris merupakan hal yang sangat penting dan mengandung kandungan hukum fardu kifayah.

dan Yurimetri. Ghaila Indonesia., 1984.

Hilman Hadikusuma, Pokok-pokok Pengertian Hukum Adat. Bandung: Alumni Bandung, 1980

Jakarta : Rineka Cipta.

Kato, Tsuyoshi. Adat Minangkabau dan merantau dalam perspektif sejarah. Jakarta: PT Balai Pustaka., 2005.

Kunaifi, Ahmad. Kedudukan dan Peran Laki-laki dalam Masyarakat Minangkabau Bukittinggi Perantauan di Jakarta Pengaruh Terhadap Huku. Tesis Magister Kenotariatan. Semarang: Universitas Diponegoro, 2005.

L. Berger, Peter, The Sacret Canopy: Elemens of a Sosiological Theory of Relegion. New York: Anchor Books, 1967. 
L. Berger, Peter. \& Luchman, Thomas. Tafsir sosial Atas Kenyataan: Risalah Tentang Sosiologi Pengetahuan .Jakarta: LP3ES, 1990.

Rasjid, Sulaiman . Cet. 45. Fikih Islam. Bandung: Sinar Baru Algensindo, 2010.

Soehardi, A. Pengantar Hukum Adat Indonesia. N.V Penerbitan W Van Hoeve. Bandung : S-Gravenhage, 1954.

Soepomo. 1989. Bab-bab Tentang Hukum Adat. Bandung: University, 1989.

Sudiyat, Imam. Azas-azas Hukum Adat, Liberty: Yogyakarta, 1985.
Sugangga, I.G.N. Hukum Waris Adat. Semarang : Universitas Diponegoro, 1995.

Sukanto. Meninjau Hukum Adat. Jakarta: Gunung Agung, 2001.

Syarifuddin, Amir. Cet. III. Hukum Kewarisan Islam. Jakarta: Kencana, 2008.

Usman, Suparman. Dan Somawinata, Yusuf. Fikih Mawaris. Jakarta: Gaya Media Pratama., 1997

Vollenhoven, Penemuan Hukum Adat. Jakarta : Djambatan, 1987. 